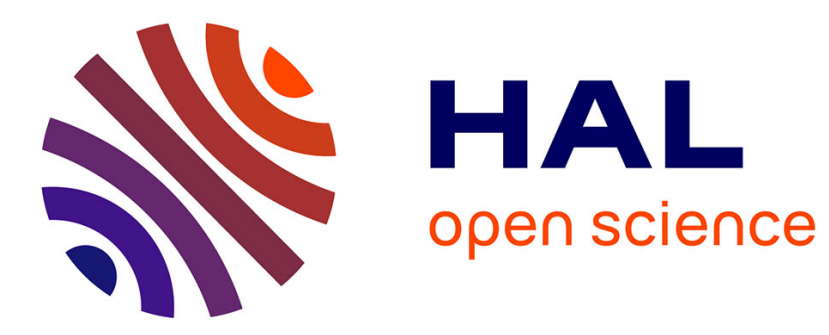

\title{
Preparation of Onboard Reforming Catalyst for Methanol by Chemical Vapor Deposition
}

\author{
M. Yano, K. Ohno, H. Imanaka
}

\section{To cite this version:}

M. Yano, K. Ohno, H. Imanaka. Preparation of Onboard Reforming Catalyst for Methanol by Chemical Vapor Deposition. Journal de Physique IV Proceedings, 1995, 05 (C5), pp.C5-1069-C5-1075. 10.1051/jphyscol:19955126 . jpa-00253822

\section{HAL Id: jpa-00253822 https://hal.science/jpa-00253822}

Submitted on 1 Jan 1995

HAL is a multi-disciplinary open access archive for the deposit and dissemination of scientific research documents, whether they are published or not. The documents may come from teaching and research institutions in France or abroad, or from public or private research centers.
L'archive ouverte pluridisciplinaire HAL, est destinée au dépôt et à la diffusion de documents scientifiques de niveau recherche, publiés ou non, émanant des établissements d'enseignement et de recherche français ou étrangers, des laboratoires publics ou privés. 


\title{
Preparation of Onboard Reforming Catalyst for Methanol by Chemical Vapor Deposition
}

\author{
M. Yano, K. Ohno and H. Imanaka \\ Dept. of Applied Chemistry, Faculty of Engineering, Osaka City University, 3-3-138 Sugimoto, \\ Sumiyoshi-ku, Osaka 558, Japan
}

\begin{abstract}
NiO}$ deposited on the wall of the pore of the filter by the reaction with $\mathrm{NiCl}_{2}(\mathrm{~g})$ and $\mathrm{O} 2(\mathrm{~g})$. $\mathrm{NiCl}_{2}(\mathrm{~g})$ and $\mathrm{O} 2(\mathrm{~g})$ are seprtely fed at the oppsite side of the filter(namely inner and outer side). Used alumina filter is mean pore dianeter $J \mu n$, o.d. $10 \mathrm{~mm}$, thickness $1 \mathrm{~mm}$. This $\mathrm{NiO}$ deposited filter was activated by hydrogen to form $\mathrm{Ni} / \mathrm{Al}_{2} \mathrm{O}_{3}$ catalyst, then the catalyst was measured methanol decomposition activity. From the results, increment of catalytic component increases the specific catalytic activity, but they have an optimal value of $\mathrm{Ni}$ deposition. As the shape of the catalyst is favorable to reduce the pressure drop of reactant through the catalyst, this catalyst maly be available to treat massive flow. It was found that it is a great catalyst of promise to onboard cracking for methanol automobile.
\end{abstract}

\section{INTRODUCTION}

Many works have studied for densification of preform with applying CVD[1] and CVI[2]. Scarcely studies are to prepare the caltalysts. Preparation of membrane catalyst mainly has been coated on surface of the support rather than embedding the catalyst component[3]. We attempted to prepare the membrane catalyst by embedding a catalyst component imto the alumina filter (mean pore diameter $1 \mu \mathrm{m}$, o.d. $10 \mathrm{~mm}$, thickness $1 \mathrm{~mm}$ and $20 \mathrm{~mm}$ length ). In the embedding chemical vapor deposition, $\mathrm{NiCl} 2(\mathrm{~g})$ and $\mathrm{O} 2(\mathrm{~g})$ was counter currently poured into the pore of the filter and deposited $\mathrm{NiO}$ in the pore of the filter. This catalyst are activated by hydrogen to produce a $\mathrm{Ni} / \mathrm{Al}_{2} \mathrm{O} 3$, and the rate of methanol decomposition on the calalyst was measured . From the results, the specific catalytic activity increases with the content of the catalytic component $\mathrm{NiO}$, and the optimal Ni content is present. As the shape of the catalyst is favorable to reduce the pressure drop of reactant through the catalyst, this catalyst may be available to treat massive flow. It was found that it is a great catalyst of promise to onboard cracking catalyst for methanol automobile.

\section{EXPERIMENT}

\subsection{Preparation of filler catalyst}

Alumina filter (Mitsui Whetstone Co., Multporelone) of mean pore diameter $1 \mu \mathrm{n}, 0 . \mathrm{d} .10 \mathrm{~mm}$, thickness $1 \mathrm{~mm}$ and $500 \mathrm{~mm}$ length, at the preparation, the filter is cut $20 \mathrm{~mm}$ length. The CVD rector made by quartz glass, the size is diameter $35 \mathrm{~mm}$. The length of evaporation and reaction zone are each $250 \mathrm{~mm}$ as shown in Fig.1. The alumina filter adheres to oxygen lead pipe (shown in Fig. $1 \mathrm{Cf}$ ) using ceramic cement (Toa synthetic 
Chemicals; Aronceramics-E). $20 \mathrm{~g}$ of $\mathrm{NiCl}_{2} 2 \mathrm{H}_{2} \mathrm{O}$ loaded into the evaporation port Eb and, according to the eq.(1), the evaporation temperature was adjusted to desired $\mathrm{NiCl} 2$ vapor pressure.

$$
\log \mathrm{P}=12.051-11499 / \mathrm{T}
$$

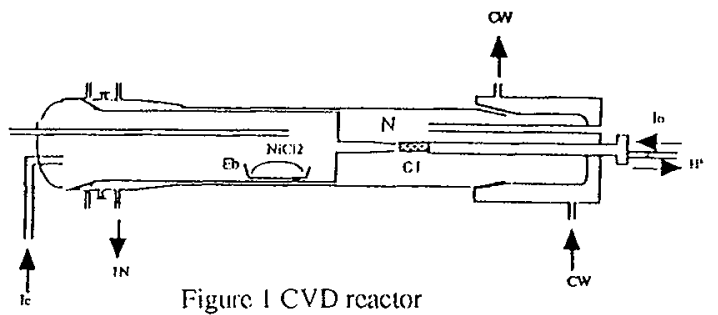

Ic; Inlet for N2 Carrier gas of $\mathrm{NiCl} 2$ In; Out iet for Reaction Products Io; Inlat for Oxygen Ip; Out let for reaction products Eb; Evaporation boat $\mathrm{Cw}$; Inlet Cooing water Cf; Ceramic filter

\subsection{Preparation mode.}

Because $\mathrm{NiCl}_{2}$ is ionic compound, the reaction $\mathrm{NiCl}_{2}(\mathrm{~g})$ and oxygen is slow under dry condition the reaction proceeds in a molecular state, and an appropriate reaction rate can be only obtained by more than 30 times of stoichiometric oxygen and the reaction temperature also more than $873 \mathrm{~K} \mid 5,6)$. But in presence of water vapor, the reaction becomes ionic reaction. Under the condition of embedding $\mathrm{NiO}$ into the pore, the lager the ratio of the reaction to the mass transfer rate, the NiO is difficult to fill deeply and homogeneously into the pore. The deposition numst operate by reaction limitted regime. Therefore the reaction took in dry condition. Then some reaction modes are devised the desired reaction performance.

\section{2.l Ractants feed with pallalel way (Mode 1);}

Carrier gas of $\mathrm{NiCl} 2$ (g) introduced to Ic(Fig.1), the gas stream released through scrubber to the atmosphere. Oxygen lead pipe consists of double tube, the outer side connects the filter with the filter with ceramic cement and the inner side of the filter closes.

Oxygen introduces to Io(Fig. 1) and pass though the filter sample and releases to atmosphere as the same way as $\mathrm{NiCl}_{2}(\mathrm{~g})$. In this case, the reactant flow pattern shmatically shows scheas mode 1 in Fig.2. The oxygen flows parallel with $\mathrm{NiCl} 2(\mathrm{~g})$ in the pore as shown in Fig.2. The mole ratio of $\mathrm{NiCl} 2(\mathrm{~g})$ and $\mathrm{O} 2(\mathrm{~g})$ and flow rates show Run 4 and 9 in

\section{Table 1.}

\subsubsection{Reactants feed into the pore by molecular diffusion (Mode 2)}

mode 1

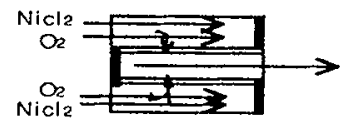

mode 2

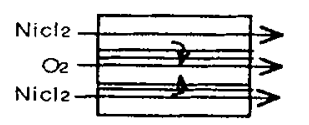

mode 3

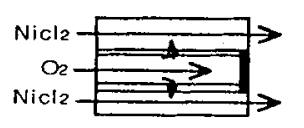

mode 4

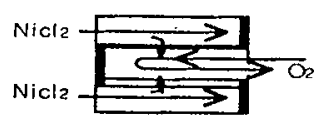

Figure 2 Schematic flow pattern reaction zone

$\mathrm{NiCl} 2$ introduces from N(Fig. 1) to the reaction zone and releases to the outlet In(Fig.1). Oxygen leads from Io and leaves Ip, and so Ip releases. In this case, let open the front side of the filter. In this way, Oxygen does not force to pass though the pores of the filter, oxygen and $\mathrm{NiCl} 2(\mathrm{~g})$ diffuse into each side of the pore.

\subsubsection{Oxygen forces to pass though the pore (Mole 3);}

The depositions steadily go on as the higher ratio of $\mathrm{O} 2 / \mathrm{NiCl} 2(\mathrm{~g})$ so that $\mathrm{NiCl} 2(\mathrm{~g})$ flows from outer to inner side of the filter. In this case, the carricr gas of $\mathrm{NiCl}_{2}(\mathrm{~g})$ kept constant at $500 \mathrm{ml} / \mathrm{min}$, and oxygen flow rates vary 5 to $40 \mathrm{ml} / \mathrm{min}$. 
2.2.4 NiCl2(g) forces to pass though the pore (Mode 4)

Table 1 Reaction condition

\begin{tabular}{|c|c|c|c|c|c|c|c|}
\hline \multirow[b]{2}{*}{ mode } & \multirow[b]{2}{*}{ Run No. } & \multirow{2}{*}{$\frac{\text { Flow rate }}{\text { Carrier N2 }}$} & \multirow{2}{*}{$\frac{[\mathrm{m}] / \mathrm{min}]}{\mathrm{O}_{2}}$} & \multirow{2}{*}{$\begin{array}{l}\text { Reaction } \\
\text { Temp.|K] }\end{array}$} & \multirow{2}{*}{$\begin{array}{l}\text { Partial } \\
\mathrm{N} 2\end{array}$} & \multicolumn{2}{|c|}{ Pressure[atm ] } \\
\hline & & & & & & $\mathrm{O}_{2}$ & $\mathrm{NiCl} 2$ \\
\hline 1 & 1 & 500 & 50 & 973 & 0.896 & $0.920 \mathrm{E}^{-2}$ & $1.10 \mathrm{E}^{-3}$ \\
\hline 2 & 2 & 500 & 200 & 1023 & 0.320 & 0.289 & $3.11 \mathrm{E}^{-3}$ \\
\hline 3 & 4 & 500 & 200 & 1023 & 0.990 & $9.90 \mathrm{E}^{-3}$ & $8.15 \mathrm{E}^{-3}$ \\
\hline 3 & 5 & 500 & 10 & 1023 & 0.800 & $1.96 \mathrm{E}^{-2}$ & $8.36 \mathrm{E}^{-3}$ \\
\hline 3 & 6 & 500 & 15 & 1023 & 0.962 & $2.09 \mathrm{E}^{-2}$ & $8.30 \mathrm{E}^{-3}$ \\
\hline 3 & 7 & 500 & 20 & 1023 & 0.954 & $3.80 \mathrm{E}^{-2}$ & $8.20 E^{-3}$ \\
\hline 3 & 8 & 500 & 30 & 1023 & 0.936 & $5.60 \mathrm{E}^{-2}$ & $8.20 \mathrm{E}^{-3}$ \\
\hline 3 & 9 & 500 & 40 & 1023 & 0.920 & $7.36 \mathrm{E}^{-2}$ & $8.05 E^{-3}$ \\
\hline 4 & 3 & 500 & 5 & 973 & 0.739 & 0.675 & $4.04 \mathrm{E}^{-3}$ \\
\hline
\end{tabular}

Outlet side of oxygen pass(Fig. l, Ip) opens, outlet side of $\mathrm{NiCl}_{2}(\mathrm{~g})$ pass(Fig. 1, In) closes, let leads $\mathrm{NiCl}_{2}(\mathrm{~g})$ stream ruming from the outside to the inner side of the filter. In this case, Ni component deposits on the outer side of the filter and little $\mathrm{NiO}$ deposited observed inner side and within the pore of the filter.

\subsection{Measurement of deposited $\mathrm{Ni}$}

Radial distribution of deposited NiO measured with EPMA(Shimazu Mnuf Co., EPMA-810) using X-ray length of $\mathrm{Ni}(1.6572 \mathrm{~A}), \mathrm{Al}(8.005 \mathrm{~A})$ and $\mathrm{Si}(7.1245 \mathrm{~A})$ were used by determining the contents, $\mathrm{Ni} \mathrm{Al}$ and $\mathrm{Si}$, respectively. In the cuantitative analysis of deposited $\mathrm{NiO}$, a few $\mathrm{mg}$ of the sample dissolved in concentrated nitric acid, and after to heat several hours,

the mixture filtrates and measures with

Induced Coupling Plasma Atomic Flame

Detector(Shimadzu Mnuf. Co., ICP-100)).

\subsection{Measurement of Methanol Decomposition Rate}

The $\mathrm{NiO} / \mathrm{Al}_{2} \mathrm{O} 3$ filter sample cements blacked parts of methanol decomposition reactor as shown in Fig. 3 the $\mathrm{Ni} / \mathrm{Al}_{2} \mathrm{O} 3$ was activated with $5 \mathrm{Vol} \%$ of hydrogen for 3 hour, and the hydrogen flow rate and the temperature are $40 \mathrm{ml} / \mathrm{min}, 623 \mathrm{~K}$, respectively. After the activation, desired partial pressure of methanol feeds to the reactor then decomposition rate measured with the reaction temperature range from 623 to $723 \mathrm{~K}$. The reaction was followed the

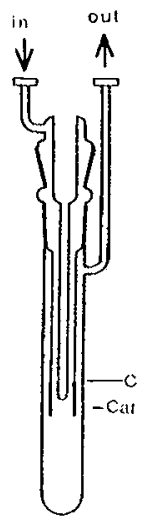

Fig. 3 Catalytic reactor products of hydrogen and carbon dioxide with gas chromatography that was equipped with $2 \mathrm{~m}$ of active carbon AA-662 30/60 mesh for hydrogen and carbon monoxide, and with $2 \mathrm{~m}$ of Porapack P 80/100mesh for methanol.

2.5 Measurement of specific surface area and Nickel metal surface area 
The specific surface area of the sample is measured by hydrogen chemisorption method[4]

\section{Results}

\subsection{Preparation mode and the distribution of deposited nickel.}

Figure 4 shows the result of preparation mode 1(dashed) and mode 2(solid line), in mode 1, the radial distribution of deposited NiO that was measured with EPMA, NiO depositts is concenteated on the outer side of the filter. And in spite of the oxygen partical pressure varies with one order, but the difference of the deposited amount and distribution does not observed within EPMA. In mode 2, the deposited NiO does not almost detected with EPMA, the fact suggests no deposition occures in the pore.

The results of mode 3 are shown in Fig.5a and b. The deposited amount is the highest at the oxygen rate of $15 \mathrm{ml} / \mathrm{min}$. The performance of this mode shows homogeneous $\mathrm{NiO}$ distribution in radial direction rather than other reaction modes, deposited NiO are in the pore of the filter. In mode 4, Ni component deposits on the outer side of the filter and little $\mathrm{NiO}$ deposited observed inner side and in the pore as shown in Fig.6.

\subsection{Properties of deposited sample}

\subsubsection{Ni contents}

In order to use deposited $\mathrm{NiO}$ sumple in methanol decomposition catalyst, the Ni contents are measured and summarized in Table 2. Catalyst are called Cat $-\mathrm{x}-\mathrm{y}, \mathrm{x}$ is number of reaction mode, $\mathrm{y}$ means run number in Table 1.

Table 2 Ni contents of Catalyst

\begin{tabular}{cc}
\hline Catalyst & Ni content[wt\%] \\
\hline Cat-3-4 & 3.37 \\
Cat-3-5 & 11.18 \\
Cat-3-6 & 21.21 \\
Cat-3-7 & 60.21 \\
\hline
\end{tabular}

\subsubsection{Catalytic properties}

$\mathrm{NiO}$ deposited sample adhered to $\mathrm{C}$ site in conventional flow reactor as shown iis Fig. 3 by ceramic cement. Methanol introduced inner side of the sample filter (as shown in Fig. 3 with inlet) and the decomposition rates were measured. In spite of closing the front end side the catalyst, the extent of methanol decomposition was not largely chainged. This mean that the rate determining step is in reaction limitied step. Then, the rates were measured under the open state of the catalyst, because it can be escape pressure drop during the methanol feed into the catalyst. The measured results are shown for each samples in Fig.7, with the conversion $[\mathrm{X}]$ as ordinate and $\mathrm{W} / \mathrm{F} \mid \mathrm{Kg} \mathrm{sec} / \mathrm{mol}]$ as abscissá.

Sample of Cat-3-4 shows about $80 \%$ of methanol conversion at the reaction temperature $573 \mathrm{~K}$ with $\mathrm{W} / \mathrm{F}=4000[\mathrm{Kg} \mathrm{sec} / \mathrm{mo})]$. All of the other results show about $100 \%$ conversion at the same temperature, therefore discriminatating between these catalytic activities, the reaction rates were measured at $503 \mathrm{~K}$, the results are shown in Fig.8.

\section{Discussion}

\subsection{Reaction mode and deposited amounts of $\mathrm{NiO}$}

Mode 1; According to $\mathrm{NiCl}_{2}(\mathrm{~g})$ and $\mathrm{O}_{2}(\mathrm{~g})$ both force to introduce from outside into inner side of the filter, the outer side concentrations of $\mathrm{NiCl}_{2}(\mathrm{~g})$ and $\mathrm{O}_{2}(\mathrm{~g})$ are higher value than that of the inner side, therefore the amount of $\mathrm{NiO}$ deposited becomes higher outside of the filter. 


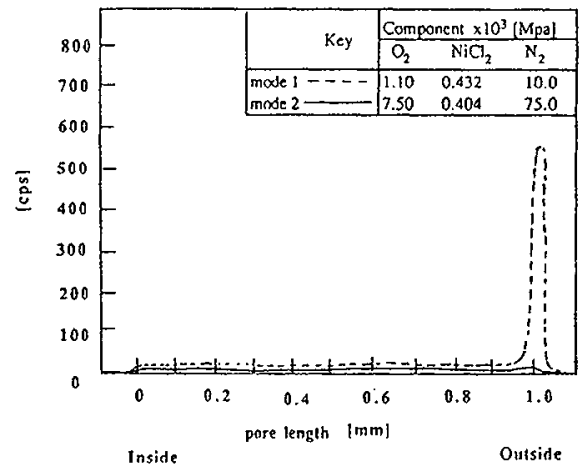

Figure 4 Radial disribution of NiO depositd from EPMA in case of mode 1 and 2

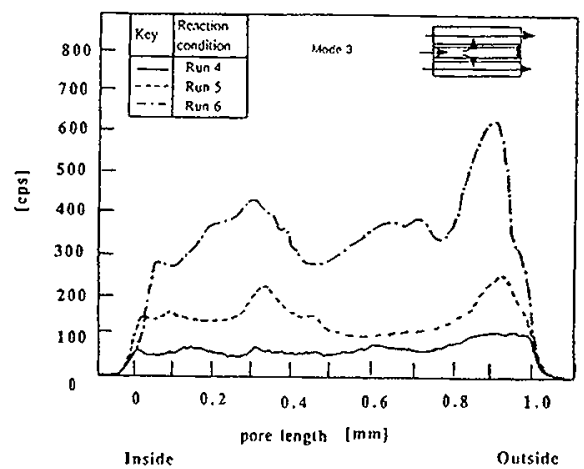

Figure $5 b$ Radiacil distribution of $\mathrm{NiO}$ deposited from EPMA in case of mode 3

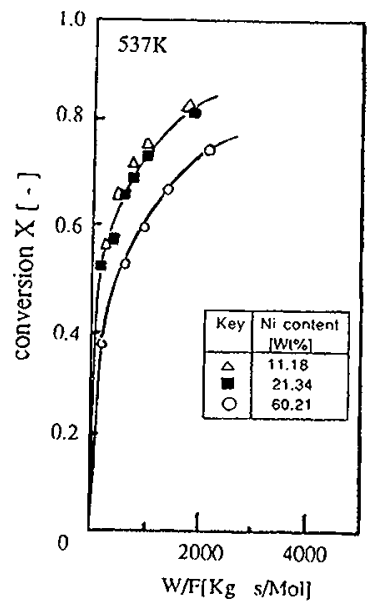

Figure 7 Methanol decomposition activity shown by W/F and conversion $x$ at $503 \mathrm{~K}$

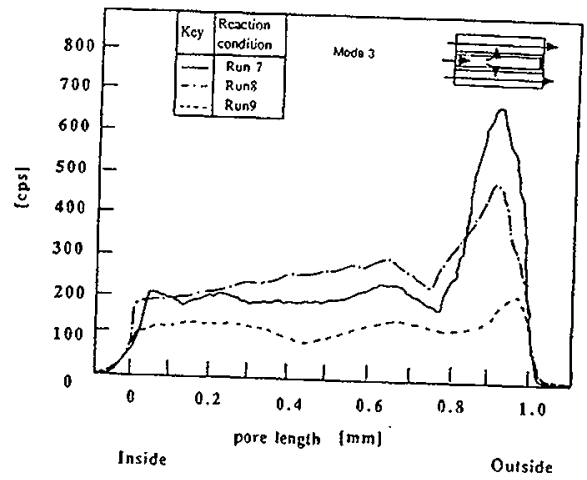

Figure 5a Radial distribution of $\mathrm{NiO}$ deposited from EPMA in case of mode 3

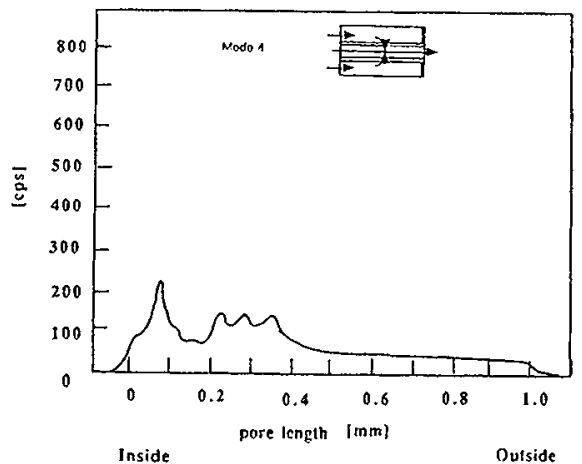

Figure 6 Radial distribution of NiO deposited from EPMA in case of mode 4

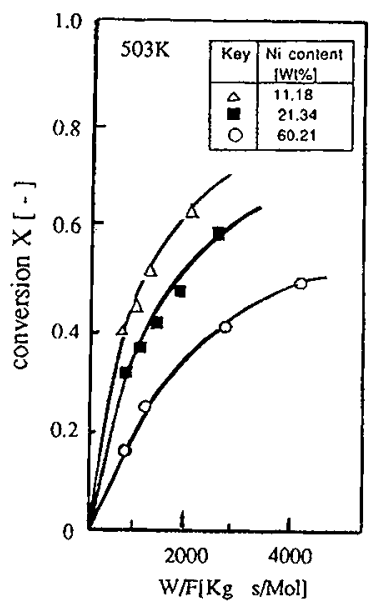

Figure 8 Methanol decomposition activity shown by $\mathrm{W} / \mathrm{F}$ and conversion $\mathrm{x}$ at $573 \mathrm{~K}$ 
Mode 2; $\mathrm{NiCl}_{2}(\mathrm{~g})$ passes though the outer part of the filter, $\mathrm{O} 2(\mathrm{~g})$ also passes through intner par of the filter, so that each components can only penetrate into the pore by pore diffusion, therefore may not expect higher reaction performance.

Mode 3; Stoichiomerically excess of oxygen feeds from inside to outside of the filter, oxygen concentration was higher than that of $\mathrm{NiCl}_{2}(\mathrm{~g})$ at the inner side of the filter. In this case, NiO homogeneously deposits in the pore.

Mode 4; $\mathrm{NiCl}_{2}(\mathrm{~g})$ feeds from outside to inner side of the filter. In this case, $\mathrm{NiCl} 2(\mathrm{~g})$ fills up in the pore and but because of insufficient oxygen concentration, large amount of $\mathrm{NiCl} 2(\mathrm{~g})$ solidifies at inner side of the filter.

Above these facts, the mode 3 is the best way to prepare unifomly deposition.

\subsection{Methanol decomposition Aclivity}

Utilization of methanol to automobile fuel possesses several advantages over fossil fuels, one of them is that methanol is free from nitrogen components, there are little NOX in the exhaust gas, and second, thermal efficiency is high because the exhaust heat can recovered by evaporation process of the methanol. Third, the methanol as fuel must not completely decompose to hydrogen and carbon monoxide, because methnol is also burn out in the engine. These advantages have already known as onboard cracking system. Here, the effectiveness of this $\mathrm{Ni} / \mathrm{Al}_{2} \mathrm{O} 3$ filter catalyst to the onboard cracking is described below.

\subsubsection{Low head loss}

Figure 7 shows catalytic activity of the filter catalyst containing nickel(Cat-3-4) $3.3 \mathrm{wt} \%$ at the reaction temperature 573K. Cat-3-5, Cat-3-6 and Cat-3-7 show all almost about $100 \%$ of extent of decomposition at $573 \mathrm{~K}$. It is desirable to able to react at $503 \mathrm{k}$ as onboard cracking catalyst. These reaction activities are shown in Fig. 8. The order of resultant activity is Cat-3-5> Cat-3-6>Cat-3-7, even at 503k, 60\% of methanol decompose at $\mathrm{W} / \mathrm{F}=1000 \mid \mathrm{Kg} \mathrm{sec} / \mathrm{Mol}$. From these capacities, if the catalyst loads on $2000 \mathrm{ml}$ of displacement capacity of engine, the feed rate repuired $235 \sim 285 \mathrm{ml} /(\mathrm{STP}) / \mathrm{min}$ of methanol. At this time, the amount of demanding catalyst is about $1.5 \mathrm{Kg}$ (abs $5 l$ ). And if we use this caltalyst for $50 \mathrm{ml}$ of displacement engine, the needed catalyst is about $40 \mathrm{~g}(36 \mathrm{ml})$. These weights and volumes are in the range of carrying capacity for scooter and bicycles.

\section{Conclusion}

Nickel supported cylindrical filter catalyst was prepared with $\mathrm{NiCl} 2+\mathrm{O}_{2}$ gas phase vapor deposition on an alumina filter which have mean porc diameter $1.5 \mu \mathrm{m}$. The homogeneous deposition had not prepared easily with conventional way, so various ways of reaction systems were altempted. As the results, the best way that nickel chloride(g) and oxygen(g) are separately fed at the oppsite side of the filter. These reaction can be appreciated over thirty times of oxygen on the stoichiometrical amount of the reaction, and the optimal reactant's ratio exists.

This NiO deposited sample was activated by hydrogen at $623 \mathrm{~K}$ and was employed decomposition of methanol as a catalyst. The extents of reactions were almost same in different two reactions conditions where one is opened and the other closed end of the catalyst. This means the reaction is not influenced by the mass transfer effect. Therefore it can be maintained constant extent of decomposition at any largely fluttering intake of engine fuel. 


\section{Literature}

1 Y.S. Lin, A.J. Burggranf, Chem. Eng. Sci., 46, 30673080 (1991)

2 S.M. Gupte, J.A.Tsamopoulos, J. Electrochem Soc., 136, 555561 (1989), ibid, idem, 137, 1626 1638(1990)

3 Philippe Cini, R. Blaha, Michael P. Harold, K. Ven Kataraman, J Membrane Sci., 55, 199225 (1991)

4 C.H. Bartholomew, R.B. Pannell, J. Ctal. 65, 390 (1980)

5 A.Gasner, I.Mayer, Bull. Res. Counc. of Israel, A8, 27 40) (1959)

6 Von K. Jellinek, A. Rudat, Z. Anorg.u.allgem. Chem., 155, 7383 (1926) 

PROCESSES FOR NEW INDUSTRIAL APPLICATIONS 
